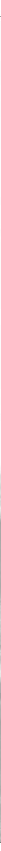

Bakgrunn: Kunnskap om ungdoms helserelaterte livskvalitet (HRLK) er sentralt $i$ et forebyggende og helsefremmende perspektiv. Det er imidlertid gjort få studier om HRLK blant ungdom i Norge.

Hensikt: $\AA$ øke kunnskapen om ungdoms HRLK ved å kartlegge HRLK hos ungdom og identifisere faktorer av betydning for deres HRLK.

Metode: Tverrsnittsstudie som inkluderer 189 ungdommer, hovedsakelig 15-16 år. HRLK ble kartlagt med KIDSCREEN-10. T-test og kjikvadrat-test ble anvendt for å undersøke forskjeller på grupper basert på henholdsvis demografiske variabler og terskelverdier for HRLK. Multippel regresjonsanalyse ble brukt for å analysere sammenhenger mellom sosiodemografiske variabler og HRLK.

Resultater: Gjennomsnittsverdien for HRLK var 71,1 (mulig skår 0-100), og egenvurdert helse viste gjennomsnitt på 2,89 (mulig skår 0-4). Jentene rapporterte signifikant lavere gjennomsnittlig HRLK og egenvurdert helse enn guttene (for begge $p=<0,001)$. Totalt 17 prosent rapporterte HRLK under nedre terskelverdi.

Den multiple regresjonsanalysen viste at kjønn og hyppig flytting var signifikant assosiert med HRLK med ustandardisert beta og $p$-verdi på henholdsvis 8,682, $p=<0,001$ og $-6,978$ og $p=0,014$.

Konklusjon: Ungdom flest opplever god HRLK. Studien indikerer at skolehelsetjenesten bør være spesielt oppmerksom på jenters utvikling av HRLK og ungdom som rapporterer lavere HRLK.
Health-related quality of life in adolescents' first year in high school

Background: Knowledge about adolescents' health-related quality of life (HRQOL) is crucial in a preventive and health promoting perspective. However, few studies have investigated HRQOL among adolescents in Norway.

Objective: To increase knowledge about HRQOL among adolescents by investigating their HRQOL and identify factors of importance for their HRQOL.

Method: Cross-sectional study including 189 adolescents, age mainly 15-16 years of age. HRQOL was measured by KIDSCREEN-10. T-test and chi-squared test were applied to investigate differences in groups based on respectively demographic variables and cut-off values for HRQOL. Multiple regression analysis was used to investigate associations between socio-demographic variables and HRQOL.

Results: The mean value for HRQOL was 71.1 (range 0 - 100) and for selfassessed health 2.89 (range 0-4). A total of $17 \%$ reported HRQOL below the lower threshold.

The girls reported significantly lower mean HRQOL and self-repor- ted health than did the boys (for both $p=<0.001)$. The multiple regression analysis revealed that gender and frequent relocation were significantly associated with HRQOL with unstandardized beta and $\mathrm{p}$-value respectively $8,682, p=<0.001$ and $-6,978, p=0.014$

Conclusion: Most adolescents experience good HRQOL. The study indicates that school health services should be aware of the development of girls' HRQOL and of adolescents that report lower HRQOL.

Keywords: Quantitative study, Adolescents, Quality of life, Health, School health services 


\section{Helserelatert livskvalitet blant ungdom forste året i videregående skole}

Forfattere: Eva Ericson, Ragnhild Sollesnes og Eva Langeland

\section{NøKKELORD}

- Kvantitativ studie

- Ungdom

- Livskvalitet

- Helse

- Skolehelsetjenesten

\section{INTRODUKSJON}

De senere årene har det vært en $ø$ kende interesse for forskning om helserelatert livskvalitet (HRLK) blant barn og unge, og egenrapportering kan gi viktig informasjon om deres HRLK $(1,2)$. Helse er et viktig element innenfor det bredere begrepet livskvalitet (LK), og defineres ulikt ut fra hvilke faglig ståsted man har (3). Ungdoms HRLK inkluderer domener som fysisk, psykisk og sosialt velvære (1). I nyere norske studier rapporter ungdom at positivt selvbilde, gode venner og familierelasjoner er viktige for deres HRLK $(4,5)$.

World Health Organization (WHO) rapporterer at 10-20 prosent av ungdom under 18 år opplever psykiske problemer, og at dette er økende. Sentrale risikofaktorer er stress og andre utfordringer i denne fasen av livet. Det er derfor viktig at man retter oppmerksomhet mot ungdommers psykososiale helse (6).

Den viktige rollen skolen har i barne- og ungdomsfasen tilsier at dette er en arena som i høy grad kan påvirke ungdommens HRLK. Utdanning er medvirkende til en rekke prosesser som bidrar til å skape helse i voksenlivet, og innvirker også på hvilke ressurser vi har til å løse problemer og mestre utfordringer (7). Skolehelsetjenesten er i en særlig gunstig posisjon til å bidra til utjevning av sosiale ulikheter i helse, samt til forebygging og tidlig avdekking og hjelp når det gjelder både psykiske, psykososiale og somatiske helseproblemer og lidelser hos barn og unge (8).

Vanligvis er ungdomstiden regnet som en «frisk» periode av livet (6). Dette støttes av norske studier som viser at HRLK hos ungdommene er gjennomsnittlig relativt høy $(9,10)$. Både norske (9-11) og internasjonale $(2,12)$ studier konkluderer med at HRLK viser kjønnsforskjeller, i form av lavere HRLK hos jenter enn gutter og at HRLK er synkende ved stigende alder hos jentene. Tidligere forskning viser at tilstedeværelse av foreldre, familie og venner er viktig for ungdoms opplevelse av livskvalitet, og at dette virker som en buffer mot lav opplevd HRLK (9,13-15). Somatisering av psykiske problemer, som hodepine, magesmerter og lignende er et tegn på dårligere HRLK hos ung- dom $(10,15)$. Faktorer som mental helse, stress, selvtillit og mestring virker inn på ungdoms HRLK og bør arbeides med gjennom programmer i skolen (16-19).

Sammenliknet med voksne har ungdoms HRLK fått liten oppmerksomhet $(10,20)$. Ungdomsårene er en sensitiv periode av livet hvor mye av grunnlaget for framtidig HRLK legges, og det er derfor viktig å få mer kunnskap om ungdommers livssituasjon. Det skal gjennomføres målrettete helseundersøkelser i løpet av det første året i videregående skole (21), og innsikt i faktorer som har sammenheng med HRLK kan bidra til at helsepersonell kan identifisere ungdom som trenger

\section{Hva tilfører denne artikkelen?}

Studien viser at de fleste norske ungdommer opplever god helseraletert livskvalitet (HRLK), men at jenter rapporterer om lavere HRLK enn gutter.

\section{Mer om forfatterne:}

Eva Ericson er helsesøster, MSc ved Laksevåg videregående skole, Bergen kommune. Ragnhild Sollesnes er førstelektor, MSc ved Høgskolen i Bergen, Institutt for sykepleiefag. Eva Langeland er dr.polit. og førsteamanuensis ved Høgskolen i Bergen, Institutt for sykepleiefag. Kontaktperson: evaeriahfk.no. 
støtte og hjelp. Hensikten med denne studien er derfor å få økt kunnskap om ungdoms HRLK det første året i videregående skole.

Følgende forskningsspørsmål ble stilt:

- Hvordan er ungdommers HRLK og egenvurderte helse?

- Er der sammenheng mellom sosiodemografiske variabler som kjønn, boforhold, studieretning, flytting og HRLK?

\section{METODE \\ Design}

For å besvare forskningsspørsmålene benyttet vi en tverrsnittsstudie. En tverrsnittsstudie er egnet til å gi en beskrivelse av en populasjon på ulike variabler på ett tidspunkt og indikere sammenhenger mellom ulike variabler.

\section{Utvalg}

Studien inkluderer ungdommer i første klasse på videregående skoler. 211 ungdommer fra fire videregående skoler i Bergen kommune ble forespurt om å delta. Totalt 189 elever besvarte spørreskjemaer. Årsakene til at 22 elever ikke deltok, var at de enten ikke var på skolen den dagen eller at de var under 16 år og ikke hadde med seg samtykkeskjema fra sine foresatte.

\section{Datainnsamling}

Denne studien er en del av et samarbeidsprosjekt mellom skolehelsetjenesten i Bergen kommune og Høgskolen i Bergen. Det ble holdt flere møter mellom prosjektleder og helsesøstre i skolehelsetjenesten for å få mest mulig korrekte og sammenfallende rekrutteringsog datainnsamlingsprosedyrer. Innsamling av data ble ledet av helsesøstre i skolehelsetjenesten og foregikk i to omganger, november 2011 og april 2012. Relevante klasser ble valgt ut i samarbeid med skolene. Det ble lagt vekt på at kjønnsfordeling og fordeling mellom studieretningene skulle være likest mulig.

Følgende sosiodemografiske data ble kartlagt om elevene: Kjønn, alder, studieretning, hvem de bor med, antall søsken, flytting siste fem år og om respondenten har en langvarig funksjonshemning, sykdom eller medisinsk tilstand. Det var mulig å opplyse om diagnose/sykdom i et eget felt. For å måle HRLK ble KIDSCREEN-10 anvendt. KIDSCREEN-10 er utviklet for å kartlegge generisk HRLK hos friske og kronisk syke barn og ungdom i alderen 8-18 år. Det bygger på et multidimensjonalt HRLK-begrep som dekker fysiske, emosjonelle, psykiske, sosiale og atferdsmessige domener, og måler HRLK fra barns og ungdoms perspektiv (22). Skjemaet vurderes til å ha god validitet og reliabilitet, med en reliabilitet målt med Cronbachs alpha på 0,81 (22), og det anses godt egnet til å måle HRLK hos barn og ungdom $(10,20)$. Skjemaet er oversatt til norsk etter standardprosedyrer (1). De ti spørsmålene i KIDSCREEN-10 inkluderer følgende spørsmål: 1) Har du følt deg frisk og sprek? 2) Har du følt deg full av energi? 3) Har du følt deg trist? 4) Har du følt deg ensom? 5) Har du hatt tid nok for deg selv? 6) Har du kunnet velge hva du vil gjøre $\mathrm{i}$ fritiden? 7) Har moren/faren din behandlet deg rettferdig? 8) Har du hatt det gøy med vennene dine?, 9) Har du klart deg bra på skolen? og 10) Har du klart å følge med på skolen? Respondentene skal svare ut fra hvordan de har hatt det den siste uken. Hvert spørsmål har fem svaralternativer, fra «Ikke i det hele tatt/aldri» til «I høy grad/alltid». Svaralternativene skåres fra en til fem og to av spørsmålene blir så omkodet slik at høyere verdier alltid indikerer bedre livskvalitet. Det regnes så en sumskår. Skårene transformeres til en $0-100$ skala hvor 100 indikerer best HRLK og 0 dårligst. I KIDSCREEN-manualen foreligger europeiske normdata med gjennomsnittsverdi og standardavvik (SD) for gruppen 12-18 år, også delt i kjønn (22). Den inneholder ikke norske normdata. Manualen indikerer også en mulighet til å beregne en veiledende tredeling av skalaen. Den anslår at 38 prosent av gruppen vil ligge innenfor det midterste område (moderat, god HRLK), 31 prosent av gruppen vil plassere seg i det nedre området, under anslått terskelverdi (lav HRLK: «å føle seg ulykkelig, i dårlig form og misfornøyd med livet $i$ forhold til familie, jevnaldrende og skole») og 31 prosent i øvre området (høy HRLK: «å føle seg lykkelig, i god form og tilfreds med livet i forhold til familie, jevnaldrende og skole») (22). Spørreskjemaet avsluttes med et overordnet spørsmål om helse: «Til vanlig, hvordan vil du si at helsen din er?», med svaralternativ fra $1=$ utmerket til $5=$ dårlig. Disse omkodes også slik at høyest skår gir best helse (22). Folkehelseinstituttet definerer egenvurdert helse som: «En helhetsvurdering av helsetilstanden, både den fysiske og den psykiske». Den som svarer, vil vanligvis vurdere og sammenlikne sin egen helsetilstand med helsetilstanden til jevnaldrende (23).

\section{Statistiske analyser}

Data ble behandlet i SPSS versjon 19 (SPSS Inc., Chicago IL). Manglende data er behandlet i henhold til instrumentmanual for KIDSCREEN-10, som tillater kun en missing av de totalt ti spørsmålene. Alle de 189 spørreskjemaene ble inkludert i studien. 
De sosiodemografiske variabler ble gjort dikotome: alder (15/16 år eller >16 år), bostatus (mor og far, eller andre som bare mor eller far, venner, annen slekt, fosterhjem), flytting (nei/en gang eller to/flere ganger) og søsken (nei eller ja). Beskrivende statistikk ble brukt for å gi en oversikt over sosiodemografiske variabler og for å beskrive utvalgets HRLK og egenvurdert helse. Uavhengig T-test ble brukt for å sammenlikne gjennomsnittlig HRLK mellom to uavhengige grupper basert på de dikotome sosiodemografiske variablene. Kjikvadrat-test ble brukt for å undersøke forskjellen mellom alle de dikotome bakgrunnsvariablene og gruppene som skåret henholdsvis under og over nedre terskelverdi. Pearson $r$ ble brukt for å se på sammenhengen mellom HRLK og egenvurdert helse. Multippel regresjonsanalyse ble anvendt for å undersøke sammenhenger mellom HRLK og sosiodemografiske variabler. HRLK ble definert som avhengig variabel og demografiske variabler som uavhengige. En p-verdi $<0,05$ ble regnet som signifikant. Reliabilitet for instrumentet beregnes ved Cronbach`s alpha.

\section{Etiske overveielser}

Studien er godkjent av Norsk samfunnsvitenskapelig datatjeneste. Det ble også gjort forespørsel til REK, som vurderte studien til å ligge utenfor framleggingsplikten. Det ble først gitt informasjon og innhentet aksept for prosjektet fra skolenes administrasjon. Standardisert informasjon ble gitt av skolens helsesøstre muntlig og skriftlig i de utvalgte klassene en uke før gjennomføringen av undersøkelsen. Deltakernes rettigheter ble sikret gjennom informert samtykke. Elever under 16 år fikk med samtykkeskjema til foresatte. Helsesøster delte ut skjema i klassene uken etter, og var til stede under utfyllingen for å svare på eventuelle spørsmål. Ungdommene brukte

prosent). Som tabell 1 viser hadde studien en liten overvekt av gutter (102 gutter og 87 jen-

\section{Ungdomsårene er en sensitiv periode av livet.}

cirka fem minutter på å fylle ut spørreskjemaet. Undersøkelsen var basert på frivillig deltakelse, og de som ikke var til stede på skolen den aktuelle dagen fikk ikke ny forespørsel. De under 16 år som ikke hadde med samtykkeskjema, deltok ikke.

\section{RESULTATER}

211 elever ble forespurt, og de 189 elevene som var på skolen den aktuelle dagen og hadde med seg samtykkeskjema fra foreldre (elever under 16 år), fullførte undersøkelsen $(89,6$ ter). Fordelingen mellom studieretningene viste en liten overvekt respondenter fra studiespesialiserende $(\mathrm{ST})$. De fleste av elevene var $15 / 16$ år, resten $(n=20)$ var mellom 17-24 år. Det var 21,6 prosent $(n=41)$ som oppga at de hadde en diagnose/sykdom. Derav var 88 prosent av diagnosene/sykdommene av fysisk art, og flest allergier. Flertallet av ungdommene bodde sammen med begge foreldrene. Kun 12 prosent av respondentene hadde flyttet to eller flere ganger de siste fem årene (tabell 1).

TABELL 1: Gjennomsnittskår HRLK' St. Error og p-verdi for demografiske variabler ( $N=189)$.

\begin{tabular}{|c|c|c|c|c|c|}
\hline & & $\%$ & $\begin{array}{l}\text { Snitt } \\
\text { HRLK }\end{array}$ & $\begin{array}{l}\text { St. } \\
\text { Error }\end{array}$ & $\mathrm{p}$ \\
\hline \multirow{2}{*}{ Kjønn } & Jenter & 46,0 & 66,26 & 1,445 & \multirow{2}{*}{$<0,001^{* * *}$} \\
\hline & Gutter & 54,0 & 75,17 & 1,072 & \\
\hline \multirow[b]{2}{*}{ Studierettning } & $Y F^{*}$ & 45,0 & 71,18 & 1,392 & \multirow[b]{2}{*}{0,92} \\
\hline & $\mathrm{ST}^{* *}$ & 55,0 & 70,99 & 1,272 & \\
\hline \multirow{2}{*}{ Aalder } & 15/16 år & 89,4 & 71,39 & 0,966 & \multirow{2}{*}{0,323} \\
\hline & Eldre $>16$ år & 10,6 & 68,38 & 3,447 & \\
\hline \multirow{3}{*}{ Diagnose } & $\mathrm{Nei}$ & 78,3 & 71,77 & 1,017 & \multirow{3}{*}{0,155} \\
\hline & & & & & \\
\hline & $\mathrm{Ja}$ & 21,7 & 68,54 & 2,253 & \\
\hline \multirow{2}{*}{ Bostatus } & Mor og far & 69,4 & 72,15 & 1,067 & \multirow{2}{*}{$0,043^{* * *}$} \\
\hline & Andre ${ }^{\circ}$ & 30,6 & 68,03 & 1,870 & \\
\hline \multirow{2}{*}{ Flytting } & Nei/1 gang & 87,8 & 72,02 & 0,938 & \multirow{2}{*}{$0,002^{* * *}$} \\
\hline & $2->5$ & 12,2 & 63,37 & 3,265 & \\
\hline \multirow[b]{2}{*}{ Søsken } & $\mathrm{Nei}$ & 6,5 & 73,13 & 3,244 & \multirow[b]{2}{*}{0,593} \\
\hline & $\mathrm{Ja}$ & 93,5 & 71,12 & 0,962 & \\
\hline
\end{tabular}

${ }^{1} \mathrm{HRLK}=$ Helserelatert livskvalitet. ${ }^{*} \mathrm{YF}=$ Yrkesfaglig, ${ }^{* *} \mathrm{ST}=$ Studiespesialiserende $* * * p=$ signifikant $<0,05$

${ }^{\circ}$ Andre $=$ mor, far, andre (venner, samboer, slekt, fosterhjem) 
TABELL 2: Kjikvadrat-test basert på sosiodemografiske og kliniske variabler og HRLK $\mathrm{K}^{1}$ over og under nedre terskelverdi (HRLK=58,3).

\begin{tabular}{|c|c|c|c|c|}
\hline & & $\begin{array}{l}\text { Lav skår } \\
\text { HRLK < 58,3 } \\
(\mathrm{N}=32) 17 \%\end{array}$ & $\begin{array}{l}\text { God til høy } \\
\text { HRLK >=58,3 } \\
(N=157) 83 \%\end{array}$ & \\
\hline & & $\%$ & $\%$ & $\mathrm{p}$ \\
\hline \multirow[b]{2}{*}{ Kjønn } & Jenter & 78,1 & 39,5 & \multirow[b]{2}{*}{$<0,001^{* * *}$} \\
\hline & Gutter & 21,9 & 60,5 & \\
\hline \multirow[b]{2}{*}{ Flytting } & $0-1$ gang & 75 & 90,4 & \multirow{2}{*}{$0,016^{* * *}$} \\
\hline & $2-5+$ & 25 & 96 & \\
\hline \multirow[t]{2}{*}{ Bostatus } & Mor og far & 53,1 & 72,7 & \multirow[t]{2}{*}{$0,029 * * *$} \\
\hline & Andre & 46,9 & 27,3 & \\
\hline \multirow{2}{*}{ Søsken } & Nei & 3,3 & 7,1 & \multirow{2}{*}{0,439} \\
\hline & $\mathrm{Ja}$ & 96,7 & 92,9 & \\
\hline \multirow[b]{2}{*}{ Diagnose } & $\mathrm{Nei}$ & 71,9 & 79,6 & \multirow[b]{2}{*}{0,333} \\
\hline & $\mathrm{Ja}$ & 28,1 & 20,4 & \\
\hline \multirow{2}{*}{ Studierettning } & $\mathrm{YF}^{*}$ & 43,8 & 45,2 & \multirow{2}{*}{0,879} \\
\hline & $\mathrm{ST}^{* *}$ & 56,2 & 54,8 & \\
\hline
\end{tabular}

${ }^{1} \mathrm{HRLK}=$ Helserelatert livskvalitet $* \mathrm{YF}=$ Yrkesfag, ${ }^{* *} \mathrm{ST}=$ Studiespesialiserende

$* * *$ kjikvadrat-test, $p=s$ ignifikant $<0,05$

${ }^{\circ}$ Andre $=$ mor, far, andre (venner, samboer, slekt, fosterhjem)

TABELL 3: Multippel regresjonsanalyse med HRLK som avhengig variabel og kjønn, bostatus og flytting som uavhengige variabler.

\begin{tabular}{lll}
\hline Uavhengige variabler & $\begin{array}{l}\text { Ustandardisert } \\
\text { betakoeffisient }\end{array}$ & $\mathrm{p}$ \\
Kjønn & 8,682 & $<0,001^{*}$ \\
Bostatus & $-1,605$ & 0,412 \\
Flytting & $-6,978$ & $0,014^{*}$ \\
\hline
\end{tabular}

${ }^{*} p=$ Signifikant $<0,05$

\section{HRLK og egenvurdert helse}

Reliabiliteten for KIDSCREEN-10 ble i denne studien målt til Cronbachs`alpha $=0,77$, som anses adekvat (24). Dette samsvarer med Haraldstads m.fl. sin norske studie (12), med Cronbachs alpha = 0.81 , og en europeisk studie med Cronbachs alpha $=0.79$ (25).

Gjennomsnittlig HRLK i studien var 71,1 $(S D=12,9)$. Laveste skår var 35 og høyeste skår var 100. Ifølge manualen gir dette en veiledende nedre terskelverdi på 58,3 (tabell 2). Dette indikerer at 83 prosent av respondentene hadde en god til svært god opplevelse av sin HRLK. Det var en signifikant kjønnsforskjell: jentene hadde et gjennomsnitt på 66,26 og guttene et gjennomsnitt på 75,17 (= p<0.001), se tabell 1 .

Egenvurdert helse med mulig skår fra 0-4, ga en gjennomsnitt på 2,89 $(\mathrm{SD}=0,95)$. Også egenvurdert helse viste en signifikant kjønnsforskjell $(\mathrm{p}=0,001)$ med høyest skår for guttene.

Det var en moderat positiv korrelasjon mellom HRLK og egenvurdert helse, Pearsons $\mathrm{r}=$ $0,574(\mathrm{p}=0,01)$.

Det var ingen signifikant forskjell på HRLK mellom studieretningene. Variablene diagnose og søsken viste heller ingen signifikant forskjell på HRLK. Av de respondentene som skåret lavt på HRLK var det 46,9 prosent som ikke bodde sammen med begge foreldrene $(\mathrm{p}=0,029)$. Jamfør tabell 2.

De 12 prosent av respondentene ( $n=23)$ som hadde flyttet to eller flere ganger, oppga signifikant lavere HRLK enn de som hadde flyttet ingen eller én gang $(\mathrm{p}=0,016)$, jamfør tabell 2 . Den multiple regresjonsanalysen viste at kjønn og hyppig flytting var signifikant assosiert med HRLK med ustandardisert beta og p-verdi på henholdsvis $8,682, \mathrm{p}=<0,001$ og $-6,978$ og $\mathrm{p}=0,014$, se tabell 3 .

\section{DISKUSJON}

Dette er en av få studier i Norge som har undersøkt hvordan ungdommer i Norge rapporterer sin HRLK. Hovedresultatene fra studien viste at de fleste ungdommene opplevde å ha god HRLK. Kjønn og hyppig flytting var sterkest assosiert med HRLK. Jenter rapporterte signifikant lavere HRLK og egenvurdert helse enn guttene. 
Våre funn er i samsvar med tidligere forskning om ungdoms HRLK $(6,9,10)$ og egenvurdert helse $(26,27)$. Forskning viser imidlertid at HRLK kan variere fra land til land $(22,28)$, noe som viser viktigheten av nasjonale normstandarder. I denne studien fant vi litt lavere gjennomsnittskår sammenliknet med europeiske normdata og data fra Haraldstads studie (10). Dette kan forklares med at utvalget $i$ vår studie hovedsakelig består av 15-16-åringer. De europeiske normdata og Haraldstads studier er basert på et bredere aldersspenn, og annen forskning viser at HRLK er synkende med stigende alder, spesielt for jenter (9-12). Når vi tar hensyn til aldersaspektet, samsvarer våre resultater med forventet verdi av HRLK og egenvurdert helse.

Vår studie viste at der var en moderat positiv sammenheng mellom HRLK og egenvurdert helse og at bortimot $1 / 5$ av elevene rapporterte lavere HRLK. Dette kan bety at man kan føle seg ulykkelig, i dårlig form og misfornøyd med livet i forhold til familie, jevnaldrende og skole (22). Oppfølging av denne gruppen fra skolehelsetjenesten kan være viktig for å forebygge forverring og tilrettelegge for å styrke HRLK og egenvurdert helse. Det vises til at det er sammenheng med dårlig selvrapportert helse hos ungdom og frafall i skolen (29). Spesielt overganger er utfordrende. Overgangen fra ungdomsskolen til videregående gir krav om å tilegne seg nye sosiale ferdigheter, og det forventes etter hvert at ungdommen blir mer selvstendige og tar mer ansvar for egen læring $(30,31)$. Forskning indikerer at skolerelatert stress bidrar til utvikling og opprettholdelse av subjektive helseplager, og at skolerelatert stress har vært økende i Norge, spesielt for forste året i videregående skole $(26,32)$. Økende skolerelatert stress viser at det er nødvendig å fokusere på mental helse, stress og mestring i skolen (16-18).

Breidablik m.fl. konkluderer med at selvrapportert helse viser betydelig grad av stabilitet gjennom en fireårsperiode i ungdomstiden, til tross for at denne tiden ellers preges av store endringer ved individet selv og deres omgivelser. Selv om egenvurdert helse synes stabil gjennom ungdomstiden svekkes den gradvis av mangel på generell velværefølelse, sykdom, bruk av helsetjenester og risikoatferd (33). Da vår studie hadde tverrsnittsdesign er den ikke egnet til å si noe om utvikling over tid, men andre studier har vist at også HRLK er synkende med økende alder (9-12).

I samsvar med tidligere forskning (2,9-11) fant også denne studien en signifikant kjønnsforskjell ved at guttene skåret høyere på HRLK og egenvurdert helse. Man peker på at jenter har lavere psykososial helse og selvtillit $(9,19)$, og forskning å påvirke kjønnsforskjeller i LK (34). Gutter vil kanskje underkommunisere hvordan de faktisk har det, fordi de kan være mindre vant med å erkjenne og uttrykke følelser (35).

Av gruppen som svarte at de har en sykdom eller diagnose var de fleste sykdommene/ diagnosene fysiske, og derav hovedsakelig allergier. Dette samsvarer med Ung-HUNTstudien (Helseundersøkelsen i Nord-Trøndelag), som fant at hodepine, nakke, leddsmerter og astma/allergi var de vanligste årsakene til lavere HRLK blant ungdom (36).

Vår studie viste at de som bodde både med mor og far og de som hadde flyttet ingen eller én gang i løpet av de siste fem årene, rapporterer signifikant høyere HRLK enn de som bor med bare mor eller far eller andre, eller har flyttet flere ganger. Disse funnene støtter opp om tidligere forskning som viser at miljøet rundt ungdommen, som hjemmesituasjonen, venner og skolesituasjonen er viktig for deres HRLK (9,12-14,19). Variablene bostatus og flytting kan være knyttet sammen for en del av respondentene. Endring $\mathrm{i}$ bostatus kan innebære at

\section{De fleste ungdommene opplevde å ha god HRLK.}

viser også at det er jenter som uttrykker mest somatisering av psykososiale problemer $(10,15,29)$. Forskning på mulige årsaker til kjønnsforskjeller i HRLK peker på at kvinner synes å oppleve sterkere emosjonell intensitet enn menn. Kjønnsspesifikke genetiske forhold, biologiske og psykologiske faktorer så vel som samfunnsstrukturelle forhold synes respondenten flytter, men det kan også være andre i husstanden som flytter. Cirka en tredjedel av dem som oppga å ha flyttet mye de siste årene oppga likevel at de bor sammen med mor og far. Dette kan også bety at de bodde like mye hos begge foreldrene etter samlivsbrudd. Støtte fra familie er viktig for ungdoms helse (37,38). 6-16 prosent av ungdom som opplever 
oppløste hjem kan ha problemer med å klare overgangen fra ungdomsskolen til videregående, og med å fullføre videregående skole (39). Vår studie viser i likhet med Øien m.fl. (40) ingen signifikant forskjell på HRLK mellom studieretningene.

\section{Styrker og begrensninger}

En fordel for studien har vært at helsesøster var tilgjengelig i klasserommet under utfylling av spørreskjema for eventuelle spørsmål, og alle fikk tilnærmet vurdert helse, men at cirka en femtedel faller under anslått terskelverdi for tilfredsstillende HRLK. Å være jente og hyppig flytting er assosiert med lavere HRLK. Skolehelsetjenesten bør følge opp elever som rapporterer om lav grad av HRLK generelt, og være spesielt oppmerksom på jenters utvikling av HRLK i det forebyggende helsearbeid.

Studien viser nødvendighet av å kartlegge HRLK i skolehelsetjenesten. Et kort selvrappor-

\section{Jenter rapporterte signifikant lavere HRLK.}

samme informasjon. En klassesituasjon gir vanligvis høyere svarprosent, noe som styrker studien. Klassesituasjonen kan samtidig være en ulempe i forhold til konfidensialitet og at respondentene derfor svarer det de tror er sosialt akseptert. Vi har heller ingen opplysninger om dem som ikke ønsket å delta, ikke returnerte samtykkeskjema fra foresatte eller de som ikke var til stede den aktuelle dagen. Helseproblemer kunne være årsak til at noen elever var fraværende.

Denne studien har anvendt en nedre terskelverdi for HRLK for å kunne identifisere ungdommer som kan ha behov for videre oppfølging. Det er viktig å understreke at terskelverdi kun gir en indikasjon, da blant annet dagsform virker inn på hvordan man rapporterer HRLK. Vurdering av HRLK i form av spørreskjema må derfor alltid suppleres med samtaler for å få et bedre vurderingsgrunnlag.

\section{Konklusjon}

Studien avdekker at de fleste opplever god HRLK og egen- teringsskjema tidlig i skoleåret vil kunne bidra til å få kontakt med elever som kan ha behov for oppfølging fra skolehelsetjenesten, og slik være et supplement til andre metoder for innhenting av opplysninger som journaler og samarbeid med skole, foresatte og elever. Dette kan så være utgangspunkt for en målrettet helseundersøkelse.

Det er nødvendig med videre kartlegging og oppfølging over tid for å lage norske normdata, og se trender og effekter av igangsatte tiltak. Det bør også utvikles et felles kartleggingsverktøy med gode norske normdata til bruk i skolehelsetjenesten i videregående skoler. Dette kan også være til hjelp på individuelt plan, til identifisering av elever som trenger spesiell oppfølging fra skolehelsetjenesten.

Det er behov for mer forskning på ungdoms HRLK i Norge. Dette gjelder både tverrsnittsstudier og oppfølgingsstudier, og da med større utvalg enn i vår studie. Mer forskning om hvordan vi kan tilpasse tiltak og forhold for å utjevne kjønnsforskjeller og sosiale ulikheter innen folkehelsearbeidet er nødvendig.

Tusen takk til helsesøstergruppen og skolene som har vært med i planlegging og gjennomføring av prosjektet, og til alle elevene som har deltatt i studien.

\section{REFERANSER}

1. Haraldstad K. Health - related quality of life and pain in children and adolescents. The Norwegian KIDSCREEN-study [doktoravhandling]. Bergen: Universitetet i Bergen; 2011. 2. Petersen-Ewert $C$, Erhart $M$, Ravens-Sieberer. Assessing healthrelated quality of life in European children and adolescents. Neuroscience and Biobehavioral Reviews. 2011;35:1752-6.

3. Wahl AK, Hanestad BR. Måling av livskvalitet $\mathrm{i}$ klinisk praksis. En innføring. Bergen: Fagbokforlaget; 2004. 4. Helseth S. Livskvalitet hos barn og unge. I: Haugland S., Misvær N. red. Håndbok for skolehelsetjenesten. Oslo: Kommuneforlaget; 2009. s. 329-35.

5. Helseth S, Misvær N. Adolescents perseption of quality of life: what it is and what matters. Journal of Clinical Nursing. 2010;19:1454-61.

6. World Health Organization. A snapshot of the health of young people in Europe a report prepared for the European commission conference on youth health. Brussel: World Health Organization; 2009. [Nedlastet: 2012 -01-25] Tilgjengelig fra: http://www. euro.who.int/__data/assets/pdf_ file/0013/70114/E93036.pdf.

7. Elstad JI. Utdanning og helseulikheter. Problemstillinger og forskningsfunn. Oslo: Helsedirektoratet; 2008. IS-1573.

8. Helsedirektoratet. Utviklingsstrategi for helsestasjons- og skolehelsetjenesten. Oslo: Helsedirektoratet; 2010. IS-1798.

9. Helseth S, Christoffersen KA, Lund T. Helserelatert livskvalitet hos ungdom-som grunnlag for tilnærming i skolehelsetjenesten. Vård i Norden. 2006 Januar; 27:15-21.

10. Haraldstad K, Christoffersen KA, Eide H, Natvig GK, Helseth S. Predictors of health-related quality of life in a sample of children and adolescents: a school survey. Journal of Clinical Nursing. 2011; 20: 3048-56.

11. Jozefiak T, Larsson B, Wichstrøm L. Changes in quality of life among Norwegian school children: a six-month 
follow-up study. Health and Quality of Life Outcomes. 2009;7:1-12.

12. Michel G, Bisegger C, Fuhr DC, Abel $\mathrm{T}$, The Kidscreen group. Age and gender differences in health-related quality of life of children and adolescents in Europe: a multilevel analysis. Quality of Life Research. 2009; 18: 1147-57.

13. Turagabeci. AR. Nakamura K, Kizuki M, Takano T. Family structure and health, how companionship acts as a buffer against ill health. Health and Quality of Life Outcomes. 2007; 5: 1-9. 14. Giannakopoulos G, Dimitrakaki C, Pedeli X, Kolaitis G, Rotsika V, RavensSieberer U, Tountas, Y. Adolescents wellbeing and functioning: relationships with parents' subjective general physical and mental health. Health and Quality of Life Outcomes. 2009;7:100. 15. Henje Blom EC, Serlachius E, Larsson JO, Theorell T, Ingvar M. Low Sense of Coherence (SOC) is a mirror of general anxiety and persistent depressive symptoms in adolescent girls - a cross-sectional study of a clinical and a non-clinical cohort. Health and Quality of Life Outcomes. 2010;8:1-13.

16. Barnes VA, Bauza LB, Treiber FA. Impact of stress reduction on negative school behavior in adolescents. Health and Quality of Life Outcomes. 2003;1:10. 17. Rajmil L, Palacio-Vieira JA, Herdman M, López-Aguilà S, VillalongaOlives EM, Valderas J, Espallargues M, Alonso J. Effect on Health-related Quality of Life of changes in mental health in children and adolescents. Health and Quality of Life Outcomes. 2009;7:1-7.

18. World Health Organization. Evidence for gender responsive actions to promote well-being. København: World Health Organization; 2011. [Nedlastet: 2012-02-02] Tilgjengelig fra: http://www.euro.who.int/en/ what-we-do/health-topics/Life-stages/ child-and-adolescent-health/publications/2013/young-peoples-health-asa-whole-of-society-response-series/ evidence-for-gender-responsiveactions-to-promote-well-being.

19. Kvarme LG, Haraldstad K, Helseth S, Sørum R, Natvig GK. Assosiations between general self-efficacy and health-related quality of life among 12-13-year-old school children: a cross-sectional survey. Health and Quality of Life Outcomes 2009; 7:85.

20. Haraldstad K, Christoffersen KA, Eide H, Natvig GK, Helseth S. Health related quality of life in children and adolescents: Reliability and validity of the Norwegian version of KIDSCREEN-52 questionnaire, a cross sectional study. International Journal of Nursing Studies [elektronisk artikkel]. 2011b Mai: 573-581.
21. Sosial-og helsedirektoratet. Kommunenes helsefremmende og forebyggende arbeid i helsestasjonsog skolehelsetjenesten. Veileder til forskrift av 3. april 2003 nr. 450. Oslo: Sosial-og helsedirektoratet, 2004

22. The KIDSCREEN Group Europe. The KIDSCREEN Questionnaires - Quality of life questionnaires for children and adolescents. Tyskland: Pabst Science Publisher: 2006.

23. Folkehelseinstituttet. Helsetilstanden i Norge: Egenvurdert helse. Oslo: Folkehelseinstituttet; 2008. Tilgjengelig fra: http://www.fhi.no/ artikler/?id=70815.

24. Polit DF, Beck CT. Nursing research: generating and assessing evidence for nursing practice. Philadelphia: Wolters Kluwer Health; 2012. 25. Ravens-Sieberer U, Erhart M, Rajmil L, Herman M, Auquier P, Bruil J, Power M, Duer W, Abel T, Czemy L, Mazur J, Czimbalmos A, Tounta Y, Hagquist C, Kilroe J, European KIDSCREEN Group. Reliability, construct, and criterion validity of the KIDSCREEN 10 score: a short measure for shildren and adolescents' well-being and healthrelated quality of life. Quality of Life Research 2010 19: 1487-1500.

26. Samdal 0, Bye HH, Torsheim $\mathrm{T}$, Birkeland MS, Diseth ÅR, Fismen AS, Haug E, Leversen I, Wold B. Sosial ulikhet i helse og læring blant barn og unge. Bergen: Senter for forskning for helsefremmende arbeid, miljø og livsstil ved Universitetet i Bergen; 2012:2. 27. Breidablik HJ. Selvopplevd helse hos barn og unge: en undersøkelse av samvarierende og predikerende faktorers betydning for selvopplevd helse [doktoravhandling]. Bergen: Universitetet i Bergen; 2012.

28. Erhart M, Ottava V, Gaspar T, Jericek H, Schnohr C, Alikasifoglu M, Morgan A, Ravens-Sieberer U, Health Behaviour in School-aged children Positive Health Focus Group. Measuring mental health and well-being of school-children in 15 European countries using the KIDSCREEN-10 Index. International Journal of Public Health [Elektronisk artikkel]. 2009;54:160-166

29. De Ridder KAA, Pape K, Johnsen R, Westin S, Holmen TL, Bjørngaard JH. School dropout: a major health challenge: a 10-year prospective study on medical and non-medical social insurance benefits in young adulthood, the Young-HUNT 1 Study (Norway). Journal of Epidemiology \& Community Health. 2012 Februar [Nedlastet 2012-01-15]: Tilgjengelig fra: http://jech.bmj.com/ content/early/2012/01/17/jech-2011200047.full.

30. Gulbrandsen LM, red. Urie Bronfenbrenner: En økologisk utviklings- modell. I: Guldbrandsen LM., red. Oppvekst og psykologisk utvikling. Innføring i psykologiske perspektiver. Oslo: Universitetsforlaget; 2008. S. 50-71.

31. Langaard K, Toverud R. Youth Counselling in School Health Services: The Practice of 'Intentional Attentiveness'. Vård i Norden. 2010;30:32-6.

32. Torsheim T, Wold B. School-related stress, support and subjective health complaints among early adolescents: a multilevel approach. Journal of Adolescence. 2001;24:701-713

33. Breidablik HJ, Meland E, Lydersen S. Self-rated health during adolescence: stability and predictors of change (Young-HUNT study, Norway) European Journal of Public Health. 2008;19:73-78.

34. Næss S, Moum T, Eriksen J, red. Livskvalitet. Forskning om det gode liv. Bergen: Fagbokforlaget; 2012

35. Schei B, og Bakketeig L. red. Kvinner lider - menn dør. Oslo: Gyldendal Akademisk; 2007.

36. Krokstad S, Skjei Knudtsen M. red. Folkehelse i endring. Helseundersøkelsen Nord-Trøndelag. HUNT 1 (1984-86) - HUNT 2 (1995-97) - HUNT 3 (2006-08). Levanger: Hunt forskningssenter; 2011.

37. Rustad EC, Samdal 0. Hvilke betydning har støtte fra foreldre, venner og lærer for norske 15-åringers livstilfredshet? Sykepleien Forskning. 2009;4: 90-9

38. Nygren K, Bergström E, Janlert U, Nygren K. Parents matter - but relations to parents do not explain gender differences in self-reported health in adolescents. Scandinavian Journal of Caring Science. 2012; 26: 643-53.

39. Steele F, Sigle-Rushton W, Kravdal

$\emptyset$. Consequences of family disruption on children's educational outcomes in Norway. Demography [elektronisk artikkel]. 2009;46:553-74

40. Øien I, Langeland E, Natvig GK. Mestring og helserelatert livskvalitet blant ungdom i videregående skole. Norsk Tidsskrift for Sykepleieforskning. 2009;11:41-50.

Les kommentaren på side 164 > 